Bacik, R., Fedorko, R., Gavurova, B., Ivankova, V., \& Rigelsky, M. (2020).

Differences in financial performance between various categories of hotels in the

Visegrad Group countries. Journal of International Studies, 13(2), 279-290.

doi:10.14254/2071-8330.2020/13-2/19

\title{
Differences in financial performance between various categories of hotels in the Visegrad Group countries
}

\section{Radovan Bacik}

Faculty of Management, University of Prešov in Prešov,

Slovak Republic

radovan.bacik@,unipo.sk

\section{Richard Fedorko}

Faculty of Management, University of Prešov in Prešov,

Slovak Republic

richard.fedorko@,unipo.sk

\section{Beata Gavurova}

Faculty of Management and Economics,

Tomas Bata University in Zlin,

Crech Republic

gavurova@utb.cz.

\section{Viera Ivankova}

Faculty of Management, University of Prešov in Prešov,

Slovak Republic

viera.ivank.ova@smail.unipo.sk, ivankova.vierka@gmail.com

\section{Martin Rigelsky}

Faculty of Management, University of Prešov in Prešov,

Slovak Republic

martin.rigelsky@,smail.unipo.sk, martin.rigelsky@gmail.com

Abstract. Under market economy, financial health of businesses is one of the main determinants in achieving business objectives and building a competitive advantage. The objective of the study is to evaluate differences in the selected financial indicators across the categories of hotels in the Visegrad Group countries. This objective was achieved by testing these differences in the selected financial indicators (CF, EVA, ROE, ROCE, ROA, ROS and many others) for various hotel categories (two- to five-star hotels). Hotel category data (stars) were collected from Booking.com, financial outcomes were obtained directly from the financial statements of the analysed hotels. Testing of differences was carried out by non-parametric tests (Kruskal-Wallis test, Wilcoxon test). Statistically

Received: September, 2019 1st Revision: January, 2020 Accepted: May, 2020

DOI:

$10.14254 / 2071$ 8330.2020/13-2/19 
significant differences were found in CF, EVA, ROS, Profit margin, EBITDA margin, EBIT margin, Solvency ratio Asset, Turnover time, Current Liabilities Turnover. The outputs of the analyses reveal that hotels of a higher category show better financial outputs. Therefore, in order to increase their financial performance, lower category hotels should be inspired and focused on the activities of higher category hotels. The study points to the fact that the variable of hotel category should be taken into account in any analytical processes focused on the financial health of hotels.

Keywords: hospitality sector, financial health, profitability, disparities, Visegrad Group, hotels.

JEL Classification: C58, O16

\section{INTRODUCTION}

International tourism is an integral part and a driving force of economic growth in many countries (Brida et al., 2016; Lukianenko et al., 2019; Roskladka et al., 2018; Siskos and Darvido, 2018), which may be due to the fact that it is a very fast-growing area of services that brings many benefits to individual economies. The relationship between tourism and economic growth depends on various factors (PabloRomero and Molina, 2013; Carrillo-Hidalgo and Pulido-Fernández (2018)), which is also the reason for the growing interest of professional society in examining the issue of tourism from different perspectives (Stefko et al., 2018). Considerable attention has been paid to hotels as an essential element of tourism (Chen, 2011, Sainaghi et al., 2013, Yang et al., 2017, Botta, 2019). Environment in which hotels operate is characterized by dynamism, competition and considerable pressure on efficiency and performance (Oliveira et al., 2013, Arbelo-Perez et al., 2017), emphasizing the importance of focusing on financial health and conditions of hotels. The present study is focused on the financial health of hotels in the Visegrad Group and on identification of differences in the achieved financial performance from an international perspective. The choice of countries can be easily explained. The Visegrad Group reflects the efforts of the countries of the Central European region to work together in a number of fields of common interest within the allEuropean integration. Czechia, Hungary, Poland and Slovakia have always been part of a single civilization sharing cultural and intellectual values and common roots in diverse religious traditions, which they wish to preserve and further strengthen (VG, 2020). This study can contribute to the dissemination of knowledge and values in the financial field, which is also the emphasis for the Visegrad Group.

\section{LITERATURE REVIEW}

Performance can be viewed from different perspectives (see Pacheco, 2019), while Richard et al. (2009) stated that the performance of organizations represents three specific areas of business performance: (i) financial performance (profits, return on assets, return on investment and others); (ii) market performance (sales, market share and others); and (iii) return to shareholders (total return on shareholders' equity ratio, economic value added - EVA and others). At this point, it needs to be emphasized that the performance and its examination are important in many areas of countries' economies (Kliestik et al. 2020, Adamisin et al. 2017, Vozarova et al. 2019). Therefore, we consider the monitoring of performance to be important also in the field of tourism and hospitality industry (Assaf a Josiassen 2012). Given that the tourism is an important part of countries' economies (Liu and Wu 2019, Cardenas-Garcia et al. 2015), this claim has a 
significant basis. The findings of several studies revealed that the development of tourism supports the economy and the financial performance in business (Chen 2007, Fayissa et al. 2008). On the other hand, Joppe and $\mathrm{Li}$ (2016) highlighted the social aspect of tourism more than the economic aspect, arguing that the volume and structure of tourism is determined by the consumption of tourists. There are many studies that dealt with the performance of tourism and hotels from different perspectives (Sainaghi et al. 2017, Matijova et al., 2020; Lipianin-Zontek and Szewczyk, 2019; Saleh et al., 2018), for example in terms of innovation (Mattsson and Orfila-Sintes 2014), human resources (Cheung et al. 2014), hotel owner's corporate strategies (Xiao et al. 2012), customer satisfaction (Phillips et al. 2017; Ključnikov et al., 2018) or tourism destination competitiveness (Hanafiah et al. 2016). Alternative methods provide a picture of hotel performance in qualitative terms (Sainaghi et al. 2013, Vila et al. 2010), but this study focuses on the financial aspects of the performance of hotels in star classification, which is considered as a common and accessible identifier in studies dealing with the hotel industry (Israel 2002, Becerra et al. 2013, Yang and Cai 2016). The International Labor Office (1989) offers five basic methods for measuring the economic performance of hotels: (i) a valued-added-based method, (ii) a gross profit-based method, (iii) a sales or revenue-based method, (iv) an occupancy-based method, and (v) a spending-based method. Jagels (2007) revealed that liquidity, activity, profitability and operational indicators are able to measure the financial performance of hotels. The performance of hotels can also be assessed using several financial and economic indicators, such as profit (Claver-Cortes et al. 2006, Xiao et al. 2012), revenues (Xiao et al. 2012, Yang a Cai 2016), indebtedness (Mucharreira et al. 2019), return on assets - ROA a return on equity - ROE (Chen 2010, 2011, Costa a Costa 2019), stock performance (Chen 2010) or occupancy rates (Claver-Cortes et al. 2006, Chen 2010, Yang et al. 2017).

Modern trends in the use of hotels show significant changes in consumer behavior, especially in countries that have undergone a political transformation (Redo, 2015, Printeric, 2017). On the one hand, they are caused by the enrichment of society (Jankowska, 2014), on the other hand, by increasingly common access to global technologies (Cherniavska, 2015). The activities of the countries practicing in many sectors of the so-called creative economics (Krawiec and Noga, 2017).

By using a meta-analysis, Assaf and Josiassen (2016) identified more than 50 studies that dealt with measuring and comparing the performance of international hotels. The analysis of differences was carried out in several studies, for example, the findings revealed by Mucharreira et al. (2019) did not show a significant statistical difference in hotel indebtedness. Pereira-Moliner et al. (2011) examined the differences in the performance of hotels within the same group and between groups of hotels, while the authors found the existence of differences in both cases. These findings are consistent with the results of the study by McNamar et al. (2003), who emphasized that the differences in performance within groups were significantly greater than the differences between groups, as evidenced by the fact that $82.6 \%$ of the total ROA variance was found within groups. Claver-Cortes et al. (2006) examined the differences in performance expressed by occupancy and profit indicators of 3 to $5 *$ hotels divided into groups according to competitive strategies. From all the analysed indicators, a statistically significant difference between groups was found in the occupancy rate per room and bed and the total gross profit. At the same time, the authors also emphasized that the higher the hotel category, the higher the gross profit per room and per day. Pine and Phillips (2005) also agreed that the more stars a hotel had, the better its performance was. This fact was proved by Oliveira et al. (2013), whose findings showed that $5^{*}$ hotels generated a higher efficiency of revenue than $4^{*}$ hotels. Pereira-Moliner et al. (2011) as well as McNamara et al. (2003) highlighted the possible causes of the differences, and the bargaining power of businesses can be considered as one of the main causes. Dimitric et al. (2019) confirmed the difference in the profitability of hotels in selected Mediterranean countries (Croatia, Greece, Spain and Portugal) using indicators such as ROA, cash flow operating revenue, net asset turnover, solvency ratio, while their findings showed that the cash flow to operating revenue had a 
statistically significant and positive impact on profitability. Simultaneously, the authors emphasized the significance of the overall ratio of asset turnover to solvency. Based on the findings by Skuflic and Mlinaric (2015), hotel liquidity can also be added to the financial indicators that have an impact on profitability. On the other hand, Hiadlovsky et al. (2016) confirmed only a slight to a weak relationship between the liquidity and the profitability of Slovak hotels, and the authors revealed a low level of total liquidity of these hotels during the period of 2011-2014. Costa and Costa (2019) focused on identifying differences in the performance of tourism enterprises using the financial indicators such as ROA, ROE, EBITDA, GVA, solvency ratio and general liquidity. Their findings indicated that hotels in the tourism industry showed better financial performance in most indicators than other enterprises engaged in non-accommodation activities in tourism, with the exception of ROE and general liquidity. The authors revealed a significant statistical difference between hotels and other tourism enterprises, especially in EBITDA, GVA, solvency ratio, while this difference was not confirmed in ROA, ROE and general liquidity. Based on the abovementioned, it can be concluded that the difference in financial performance can be seen from different perspectives and different financial or non-financial indicators can be used. Although this issue is wellexamined, the state of the Visegrad Group hotels in this area is unknown. The purpose of this study is to examine the financial health of hotels in different categories and also to provide an international perspective on the issue. Based on this, the study can contribute to the exchange of information and values within the cooperation of the Visegrad Group countries.

\section{METHODOLOGY}

The primary objective of the study is to evaluate the difference in selected financial indicators between the categories of hotels in the Visegrad Group countries. This objective was achieved using the analysis of difference. This analysis assessed the significance of differences in selected financial indicators between the hotel categories (2 - 5-star hotels). The financial indicators were represented by Cash Flow (CF), Economic Value Added (EVA), Return on Equity (ROE), Return on Capital Employed (ROCE), Return on Assets (ROA), Return on Sales (ROS), Profit margin, Earnings before Interest and Taxes, Depreciation and Amortizations (EBITDA margin percent), Earnings before Interest and Taxes (EBIT margin), Liquidity, Solvency ratio Asset, Asset Turnover in days, Stock Turnover in days, Debts Turnover in days, Current Liabilities Turnover in days. Based on the above-mentioned objective, it is possible to determine the processes from a methodological point of view. The following research question was formulated:

RQ: Is there a difference in selected financial indicators between the categories of hotels in the Visegrad Group countries?

From the point of view of the data source, the empirical research in this study can be characterized as secondary, and from the point of view of the interconnection of scientific disciplines it is an intradisciplinary research. The analyses included the inputs represented by the standardized financial statements (2017) of hotels in the Visegrad Group countries (CZ, HU, PL, SK) and the hotel categories (hotel stars) obtained from the website booking.com (data collection - 2018).

The analyses included 585 hotels in the Visegrad Group countries. In terms of the hotel category, there were two-star hotels ** in the number of 21 (3.6\%), three-star hotels *** in the number of $229(39.1 \%)$, four-star hotels **** in the number of $302(51.6 \%)$ and 5 star hotels ***** in the number of $33(5.6 \%)$. In terms of the countries, there were 185 (31.6\%) Czech hotels, 166 (28.4\%) Hungarian hotels, 117 (20.0\%) Polish hotels and $117(20.0 \%)$ Slovak hotels. Several financial indicators could not be determined for all 
hotels due to missing data in the financial statements of hotels. The following table shows the number of individual variables entering the analyses.

Table 1

Number of variables

\begin{tabular}{|c|c|c|c|c|c|}
\hline Indicator & CF & EVA & ROE & ROCE & ROA \\
\hline N Valid & 536 & 279 & 511 & 304 & 585 \\
\hline N Missing & 49 & 306 & 74 & 281 & 0 \\
\hline Fin. Indicator & ROS & Profit margin & $\begin{array}{c}\text { EBITDA } \\
\text { margin percent }\end{array}$ & EBIT margin & Liquidity \\
\hline N Valid & 558 & 554 & 534 & 555 & 568 \\
\hline N Missing & 27 & 31 & 51 & 30 & 17 \\
\hline Fin. Indicator & $\begin{array}{c}\text { Solvency ratio } \\
\text { Asset }\end{array}$ & $\begin{array}{c}\text { Asset Turnover } \\
\text { (days) }\end{array}$ & $\begin{array}{c}\text { Stock Turnover } \\
\text { (days) }\end{array}$ & $\begin{array}{c}\text { Debts } \\
\text { Turnover } \\
\text { (days) }\end{array}$ & $\begin{array}{c}\text { Current } \\
\text { Liabilities } \\
\text { Turnover } \\
\text { (days) }\end{array}$ \\
\hline N Valid & 569 & 558 & 558 & 558 & 558 \\
\hline N Missing & 16 & 27 & 27 & 27 & 27 \\
\hline
\end{tabular}

In order to fulfil the main objective, the methods of inferential statistics and the methods of difference analysis were primarily used. The application and selection of appropriate methods were conditional on the fulfilment of assumptions such as the normality or the absence of outliers, which can distort the test outputs. The Shapiro-Wilk (SW) normality test was used to verify the normality, and the Hampel outlier test was used to detect the outliers. Based on the outputs of these tests, a non-parametric method - the KruskalWallis test was considered as an appropriate method for testing the differences. This test can only detect the differences between independent observations, but cannot determine: (i) in which categories the difference occurred and (ii) in which category the higher value was acquired. In order to complete the idea, the table of basic descriptive statistics (mean, median, standard deviation) was displayed, as well as the boxplot graphs showing the asymptotic significance of the Wilcoxon test of two independent observations.

\section{EMPIRICAL RESULTS AND DISCUSSION}

The following section is devoted to analytical processing that leads to the fulfilment of the primary objective of the research. This section is divided into three consecutive parts. The first part includes the basic statistical characteristics of descriptive statistics - mean (M), median (Med) and standard deviation (SD). In the second part, the application of the parametric method of difference detection was evaluated, as well as the most appropriate non-parametric method was chosen and applied - the Kruskal-Wallis test of $\mathrm{k}$ independent observations. The last part offers a bivariate view of the differences using the boxplot graphs and the non-parametric Wilcoxon test of two independent observations

The following Table 2 shows the outputs of the basic characteristics of the descriptive analysis in the classification of hotel categories. This information completes the idea of the financial performance of hotels in a given classification. With a focus on the mean and the median, relatively high deviations can be observed. This indicates the occurrence of extreme values and the relative differences from the normal statistical distribution. It is also advisable to focus on changes in the values of individual financial indicators between the categories of hotels. Also, when assessing the indicators, it makes sense to take into account the standard deviation. The higher this value is between the individual hotel categories in a particular financial indicator, the more different the outputs of the hotels were. 
Table 2

Basic descriptive statistic of hotel categories (stars)

\begin{tabular}{|c|c|c|c|c|c|c|c|c|c|c|c|c|}
\hline Stars & \multicolumn{3}{|c|}{ ** } & \multicolumn{3}{|c|}{$* * *$} & \multicolumn{3}{|c|}{$* * * *$} & \multicolumn{3}{|c|}{$* * * * *$} \\
\hline Stat & M & Med & $\mathrm{SD}$ & M & Med & SD & M & Med & SD & M & Med & SD \\
\hline $\mathrm{CF}$ & 153.5 & 53.7 & 291.6 & 198.6 & 74.5 & 670.3 & 765.2 & 222.8 & 2464.5 & 3027.0 & 1156.3 & 5203.6 \\
\hline EVA & 838.3 & 260.8 & 1051.3 & 893.4 & 403.5 & 1869.6 & 2820.5 & 1238.3 & 7369.3 & 8514.4 & 6102.5 & 8335.5 \\
\hline ROE $(\%)$ & 25.2 & 13.6 & 39.1 & 12.4 & 6.1 & 80.6 & 13.3 & 8.3 & 55.6 & 44.4 & 8.8 & 151.6 \\
\hline ROCE $(\%)$ & 20.5 & 5.5 & 33.9 & 0.0 & 4.4 & 56.5 & 7.9 & 5.2 & 25.9 & 6.6 & 5.9 & 7.1 \\
\hline ROA (\%) & 11.0 & 7.3 & 12.8 & 5.7 & 3.3 & 16.1 & 6.1 & 3.1 & 14.2 & 2.5 & 4.0 & 8.8 \\
\hline ROS (\%) & 4.7 & 4.2 & 9.9 & 3.1 & 3.5 & 15.4 & 7.0 & 5.9 & 20.3 & -6553.7 & 9.1 & 37707.0 \\
\hline Profit margin & 5.7 & 4.6 & 10.4 & 4.4 & 4.4 & 12.6 & 7.6 & 6.8 & 14.0 & 11.6 & 9.1 & 13.7 \\
\hline EBITDA margin & 12.3 & 10.9 & 10.0 & 12.9 & 12.3 & 12.8 & 17.6 & 17.9 & 13.5 & 23.7 & 23.8 & 17.9 \\
\hline EBIT margin & 6.4 & 5.7 & 10.2 & 6.1 & 5.6 & 12.3 & 8.9 & 8.8 & 14.0 & 12.9 & 9.3 & 13.0 \\
\hline Liquidity & 2.8 & 1.2 & 4.8 & 1.9 & 0.9 & 2.6 & 1.6 & 0.8 & 2.8 & 1.3 & 0.9 & 1.5 \\
\hline Solvency ratio Asset & 61.5 & 69.6 & 26.7 & 44.9 & 48.9 & 38.7 & 39.1 & 41.2 & 36.7 & 25.3 & 19.3 & 33.9 \\
\hline Asset Turnover (days) & 527.9 & 407.1 & 449.5 & 732.8 & 588.4 & 814.5 & 934.6 & 755.9 & 963.3 & 1537825.5 & 1054.5 & 8827758.2 \\
\hline Stock Turnover (days) & 4.5 & 3.1 & 4.2 & 7.2 & 4.1 & 11.5 & 9.5 & 5.1 & 25.0 & 8447.3 & 5.3 & 48482.8 \\
\hline Debts Turnover (days) & 13.1 & 10.8 & 12.0 & 23.3 & 8.4 & 60.6 & 25.6 & 11.2 & 98.8 & 27084.1 & 15.4 & 155497.4 \\
\hline $\begin{array}{l}\text { Current Liabilities Turnover } \\
\text { (days) }\end{array}$ & 162.8 & 40.9 & 254.8 & 246.2 & 71.3 & 621.5 & 226.8 & 107.0 & 308.0 & 57060.1 & 99.9 & 326632.4 \\
\hline
\end{tabular}

The following Table 3 evaluates the assumptions of the potential application of the parametric ANOVA test.

Table 3

Assumptions - normality and outliers

\begin{tabular}{|c|c|c|c|c|c|c|c|c|}
\hline \multirow{2}{*}{$\begin{array}{l}\text { Stars } \\
\text { Stat }\end{array}$} & \multicolumn{2}{|c|}{$* *$} & \multicolumn{2}{|c|}{ *** } & \multicolumn{2}{|c|}{$* * * *$} & \multicolumn{2}{|c|}{ ****** } \\
\hline & SW Sig. & Perc Out & SW Sig. & Perc Out & SW Sig. & Perc Out & SW Sig. & Perc Out \\
\hline $\mathrm{CF}$ & 0.000 & $10.53 \%$ & 0.000 & $7.66 \%$ & 0.000 & $8.99 \%$ & 0.027 & $10.00 \%$ \\
\hline EVA & 0.003 & $30.77 \%$ & 0.000 & $9.68 \%$ & 0.000 & $8.00 \%$ & 0.043 & $4.35 \%$ \\
\hline ROE $(\%)$ & 0.002 & $4.76 \%$ & 0.000 & $9.86 \%$ & 0.000 & $12.27 \%$ & 0.000 & $10.71 \%$ \\
\hline ROCE $(\%)$ & 0.004 & $7.14 \%$ & 0.000 & $10.00 \%$ & 0.000 & $11.52 \%$ & 0.095 & $0.00 \%$ \\
\hline ROA (\%) & 0.091 & $0.00 \%$ & 0.000 & $9.17 \%$ & 0.000 & $13.25 \%$ & 0.998 & $6.06 \%$ \\
\hline $\operatorname{ROS}(\%)$ & 0.150 & $0.00 \%$ & 0.000 & $3.67 \%$ & 0.000 & $2.80 \%$ & 0.292 & $3.03 \%$ \\
\hline Profit margin & 0.378 & $0.00 \%$ & 0.000 & $1.38 \%$ & 0.001 & $1.41 \%$ & 0.133 & $0.00 \%$ \\
\hline EBITDA margin & 0.926 & $0.00 \%$ & 0.621 & $0.48 \%$ & 0.874 & $0.61 \%$ & 0.413 & $3.45 \%$ \\
\hline EBIT margin & 0.321 & $0.00 \%$ & 0.001 & $0.92 \%$ & 0.000 & $1.05 \%$ & 0.106 & $0.00 \%$ \\
\hline Liquidity & 0.000 & $15.00 \%$ & 0.000 & $7.80 \%$ & 0.000 & $7.41 \%$ & 0.015 & $6.06 \%$ \\
\hline Solvency ratio Asset & 0.279 & $0.00 \%$ & 0.034 & $0.00 \%$ & 0.002 & $0.00 \%$ & 0.076 & $0.00 \%$ \\
\hline Asset Turnover (days) & 0.545 & $19.05 \%$ & 0.000 & $0.44 \%$ & 0.000 & $19.21 \%$ & 0.508 & $18.18 \%$ \\
\hline Stock Turnover (days) & 0.241 & $10.00 \%$ & 0.000 & $12.08 \%$ & 0.000 & $8.48 \%$ & 0.000 & $6.25 \%$ \\
\hline Debts Turnover (days) & 0.064 & $5.88 \%$ & 0.000 & $10.20 \%$ & 0.000 & $7.21 \%$ & 0.688 & $6.67 \%$ \\
\hline $\begin{array}{ll}\text { Current } & \text { Liabilities } \\
\text { Turnover (days) } & \end{array}$ & 0.001 & $4.76 \%$ & 0.000 & $3.08 \%$ & 0.000 & $0.66 \%$ & 0.001 & $0.00 \%$ \\
\hline
\end{tabular}

Note: SW Sig - Shapiro-Wilk normality test (H0: The difference from the normal distribution is not significant); Perc Out - outliers' percentage (Hampel test)

If the output of Shapiro-Wilk normality test (SW Sig) acquires a p-value less than 0.05, the significant deviations from the normal statistical distribution can be confirmed. In most cases, the normality hypothesis is rejected, as the p-value is undoubtedly less than 0.05 . When assessing the occurrence of outliers, it can be 
concluded that in many cases the outliers represent a significant proportion, often more than $10 \%$. Based on the detection of significant differences, a non-parametric alternative to the ANOVA test was selected, i.e. the Kruskal-Wallis test. The following statistical hypothesis was formulated with respect to the methodologically correct sequence of steps:

H0: Differences are not statistically significant.

The following Table 4 shows the outputs of the above-mentioned test. Based on the asymptotic significance, it is recommended to accept the previous statistical hypothesis $\mathrm{H} 0$, respectively not reject its alternative.

Table 4

Differences - Kruskal-Wallis test

\begin{tabular}{|c|c|c|c|c|c|}
\hline Fin ind & CF & EVA & ROE & ROCE & ROA \\
\hline X2 & 86.731 & 82.592 & 4.131 & 0.915 & 3.468 \\
\hline Sig & $1.10 \times 10^{-18}$ & $8.53 \times 10^{-18}$ & $2.48 \times 10^{-1}$ & $8.22 \times 10^{-1}$ & $3.25 \times 10^{-1}$ \\
\hline Fin ind & ROS & Profit margin & $\begin{array}{c}\text { EBITDA margin } \\
\text { percent }\end{array}$ & EBIT margin & Liquidity \\
\hline X3 & 9.806 & 10.779 & 23.302 & 13.294 & 3.320 \\
\hline Sig & $2.03 \times 10^{-2}$ & $1.30 \times 10^{-2}$ & $3.49 \times 10^{-5}$ & $4.04 \times 10^{-3}$ & $3.45 \times 10^{-1}$ \\
\hline Fin ind & $\begin{array}{c}\text { Solvency ratio } \\
\text { Asset }\end{array}$ & $\begin{array}{c}\text { Asset Turnover } \\
\text { (days) }\end{array}$ & $\begin{array}{c}\text { Stock Turnover } \\
\text { (days) }\end{array}$ & $\begin{array}{c}\text { Debts Turnover } \\
\text { (days) }\end{array}$ & $\begin{array}{c}\text { Liabilities } \\
\text { Turnover (days) }\end{array}$ \\
\hline X3 & 18.619 & 21.415 & 6.215 & 4.456 & 20.410 \\
\hline Sig & $3.28 \times 10^{-4}$ & $8.63 \times 10^{-5}$ & $1.02 \times 10^{-1}$ & $2.16 \times 10^{-1}$ & $1.40 \times 10^{-4}$ \\
\hline
\end{tabular}

As can be seen, in most cases (9) the asymptotic significance is less than 0.05 and even in some cases less than 0.01. In these cases, the alternative to the statistical hypothesis $\mathrm{H} 0$ is not rejected and it can be concluded that there is a demonstrable difference in selected financial indicators between the categories of hotels. This fact recommends a positive answer to our research question formulated in the methodological part of this study. The following figures illustrate the specificity of financial indicators in which there was a significant difference.

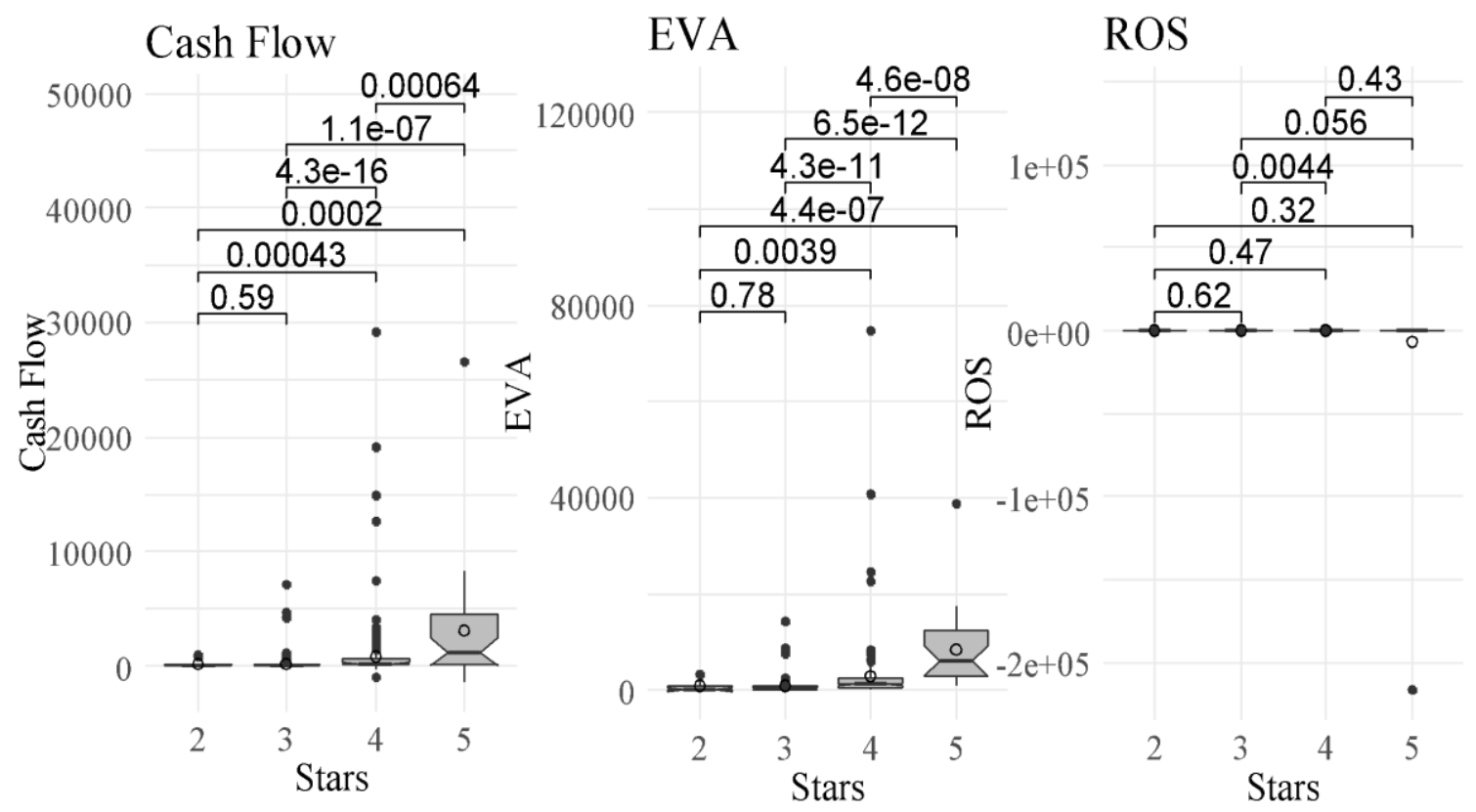

Figure 1. Visualizations of differences - CF, EVA, ROS 


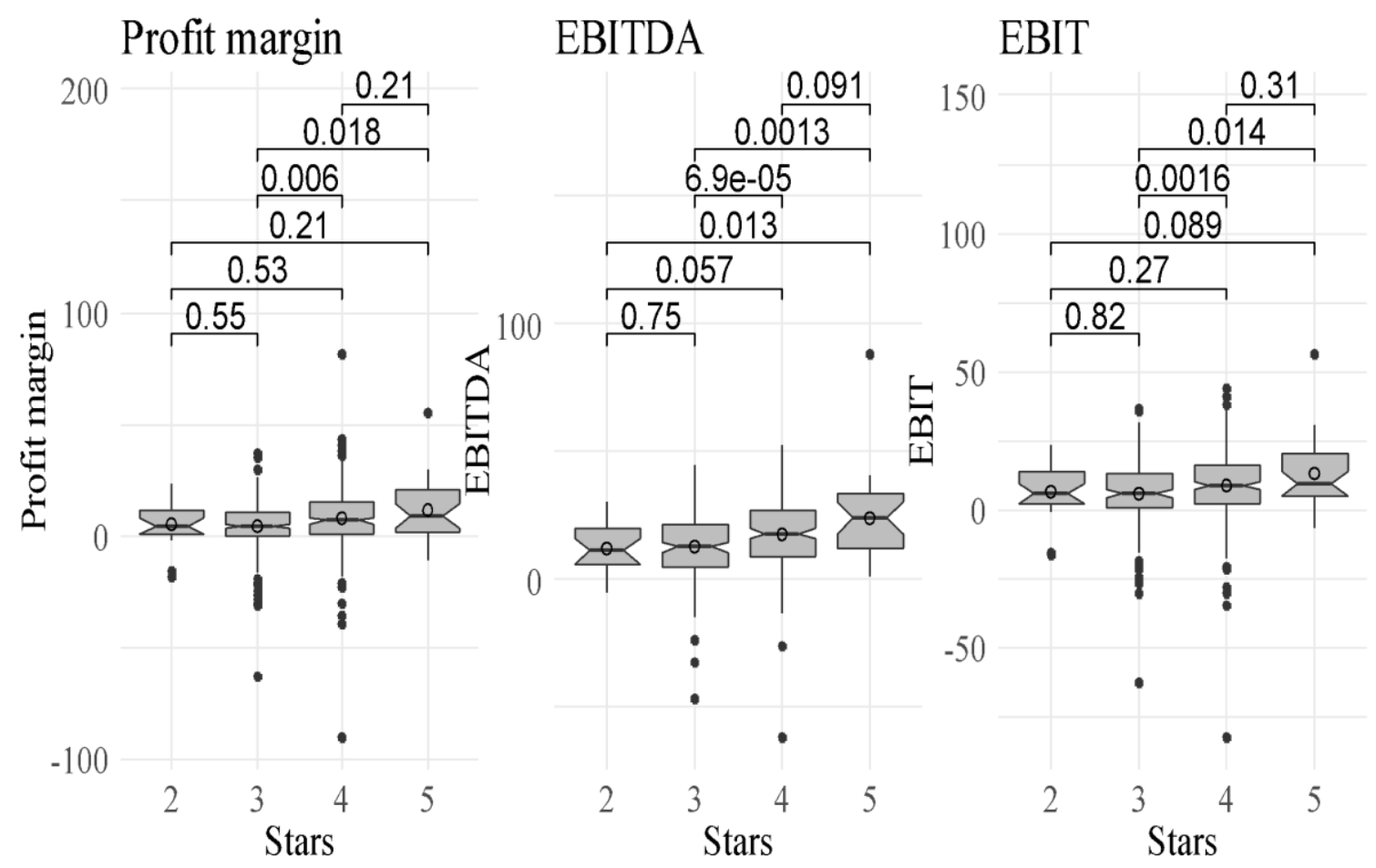

Figure 2. Visualizations of differences - Profit margin, EBITDA, EBIT

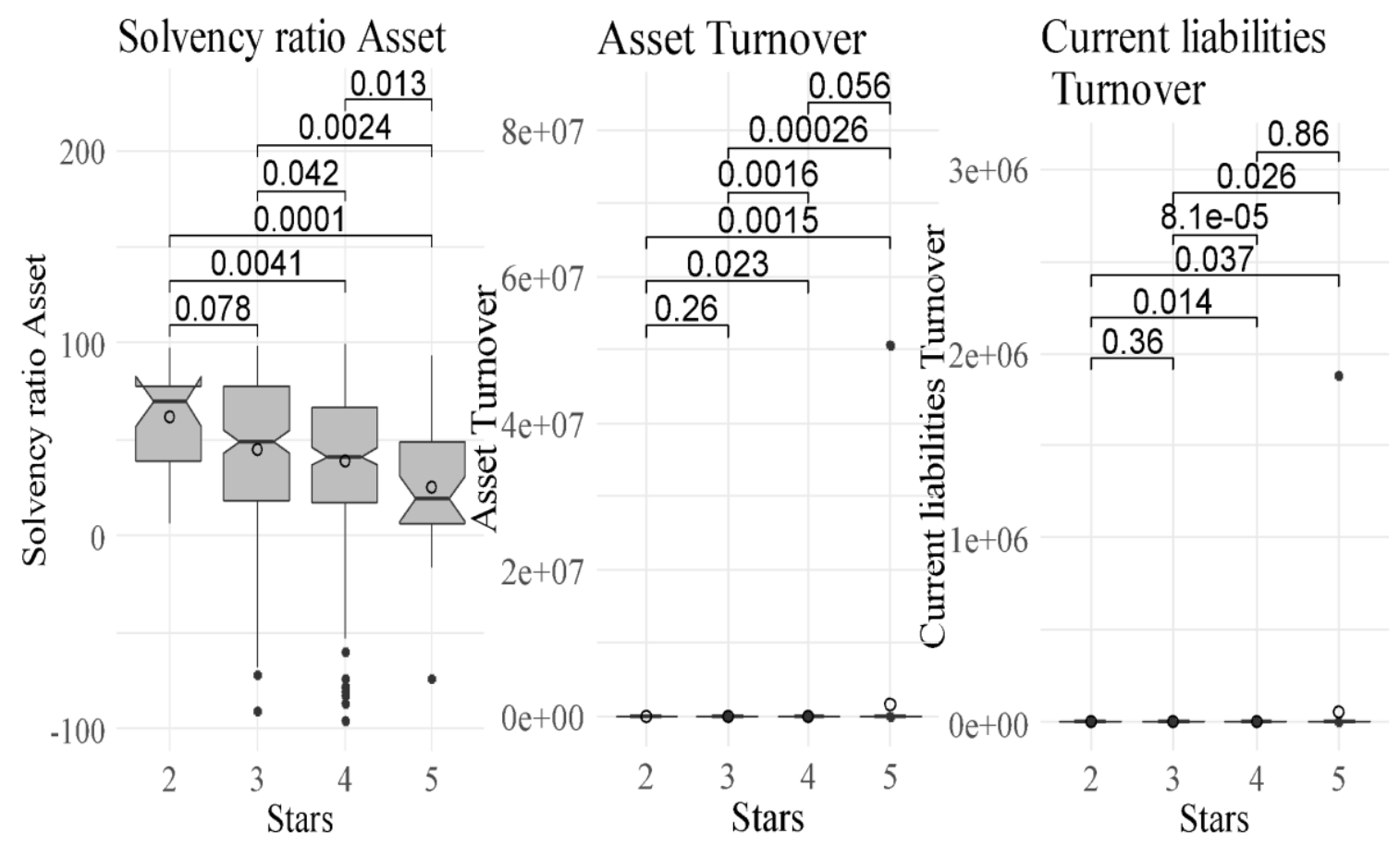

Figure 3. Visualizations of differences - Solvency ratio Asset, Asset Turnover, Current liabilities Turnover 
With a focus on Figure 1, the cash flow indicator shows the differences in all hotel categories, except the two-star and three-star categories. The asymptotic significance is less than 0.05 , i.e. the difference is confirmed. When comparing two-stars and four-stars hotels, the higher values are acquired in four-stars hotels; when comparing two-stars and five-stars hotels, the higher values are acquired in five-stars hotels. Other figures and indicators can be interpreted in a similar way. When evaluating the differences, it is appropriate to take into account the outputs of the boxplots as well as the outputs of the descriptive statistics presented in Table 2, as in several cases of graphs, the boxplots are very small due to the outliers. In the boxplots, the circle determines the average and the horizontal line determines the median.

\section{CONCLUSION}

The primary objective of the study is to evaluate the difference in selected financial indicators between the categories of hotels in the Visegrad Group countries. For this purpose, the research question was formulated as follows: Is there a difference in selected financial indicators between the categories of hotels in the Visegrad Group countries? Based on the outputs of the analyses from the previous section, the answer to this research question is positive.

The non-parametric methods of the difference analysis (Kruskal-Wallis test, Wilcoxon test) were used to meet the primary objective. The difference was found in financial indicators such as cash flow, EVA, ROS, Profit margin, EBITDA, EBIT, Solvency ratio, Asset Turnover and Current Liabilities Turnover. Therefore, it can be concluded that in most of the analysed financial outputs, the differences were identified between the categories of hotels, indicating that the individual hotel categories successfully compete for their position in the sector. These results are consistent with the findings of the study by McNamara et al. (2003), who, in addition to the differences in financial performance in the group of enterprises, also identified the differences in performance between groups. Pereira-Moliner et al. (2011) stated the same conclusion in a sample of hotels. The difference in hotel profitability was also confirmed by Dimitric et al. (2019) who dealt with hotels in selected Mediterranean countries. Our findings complement the conclusions by Costa and Costa (2019), who confirmed the differences in financial health in the tourism sector and stated that hotels show better financial performance compared to the group of enterprises engaged in other tourism activities. The analytical processes leading to the evaluation of differences between the categories of hotels have confirmed in several cases that a higher hotel category shows demonstrably better financial outcomes. This corresponds to the findings by Claver-Cortes et al. (2006) who stated that the higher the hotel category, the higher the gross profit per room and per day. Pine and Phillips (2005) also confirmed that the more stars a hotel has, the better its performance is.

The demonstrated difference points to the fact that the variable of hotel category should be taken into account in any analytical processes focused on the financial health of hotels. This variable is expected to have a demonstrable effect. The practical implications lie in the recommendations for the hotel managers, whose intention is to effectively manage and influence the financial health of the hotel. In order to increase the financial performance, hotels of lower category should be inspired and focused on the activities of higher category hotels. From a macroeconomic point of view, the improved financial health of hotels can contribute to economic prosperity through the economic gains, as the tourism sector is an important part of countries' economies. The study also provides an overview of financial performance in the tourism sector of the Visegrad Group countries. Further research activities will lead to the identification of the relations between the outputs that determine the financial health and the outputs that determine the quality of services provided. The presented research is limited mainly by the time span, as the research took into account only one year. Another potential threat may be the impact of the optimization of the tax bases by individual hotels, which can negatively affect the relevance of the overall scientific outputs on a large scale. 


\section{ACKNOWLEDGEMENT}

This article is one of the partial outputs under the scientific research grant APVV-17-0166 "Economic and psychological factors of tourists' expenditures: microeconomic modeling", VEGA 1/0694/20 "Relational marketing research - perception of e-commerce aspects and its impact on purchasing behaviour and consumer preferences" and VEGA 1/0609/19 „Research on the development of electronic and mobile commerce in the aspect of the impact of modern technologies and mobile communication platforms on consumer behavior and consumer preferences".

\section{REFERENCES}

Adamisin, P., Kotulic, R., \& Vozarova, I.K. (2017). Legal form of agricultural entities as a factor in ensuring the sustainability of the economic performance of agriculture. Agricultural Economics-Zemedelska Ekonomika, 63(2), 80-92, doi 10.17221/208/2015-AGRICECON

Arbelo-Perez, M., Arbelo, A., \& Perez-Gomez, P. (2017). Impact of quality on estimations of hotel efficiency. Tourism Management, 61, 200-208, doi 10.1016/j.tourman.2017.02.011

Assaf, A. G., \& Josiassen, A. (2012). Identifying and Ranking the Determinants of Tourism Performance: A Global Investigation. Journal of Travel Research, 51(4), 388-399, doi 10.1177/0047287511426337

Assaf, A. G., \& Josiassen, A. (2016). Frontier Analysis: A State-of-the-Art Review and Meta-Analysis. Journal of Travel Research, 55(5), 612-627, doi 0.1177/0047287515569776

Botta, M. (2019). Financing Decisions and Performance of Italian SMEs in the Hotel Industry. Cornell Hospitality Quarterly, 60(4), 335-354, doi 10.1177/1938965518816948

Becerra, M., Santalo, J., \& Silva, R. (2013). Being better vs. being different: Differentiation, competition, and pricing strategies in the Spanish hotel industry. Tourism Management, 34, 71-79, doi 0.1016/j.tourman.2012.03.014

Brida, J.G., Cortes-Jimenez, I., \& Pulina, M. (2016). Has the tourism-led growth hypothesis been validated? A literature review. Current Issues in Tourism, 19(5), 394-430, doi 10.1080/13683500.2013.868414

Cardenas-Garcia, P.J., Sanchez-Rivero, M., \& Pulido-Fernandez, J.I. (2015). Does Tourism Growth Influence Economic Development? Journal of Travel Research, 54(2), 206-221. doi 10.1177/0047287513514297

Carrillo-Hidalgo, I., \& Pulido-Fernández, J. I. (2018). Measuring the inclusiveness of international financing to tourism in Latin America and the Caribbean. Investment Management and Financial Innovations, 15(3), 15-34. doi:10.21511/imfi.15(3).2018.02

Chen, M.H. (2007). Interactions between business conditions and financial performance of tourism firms: Evidence from China and Taiwan. Tourism Management, 28(1), 188-203, doi 10.1016/j.tourman.2005.11.012

Chen, M.H. (2010). The economy, tourism growth and corporate performance in the Taiwanese hotel industry. Tourism Management, 31(5), 665-675, doi doi.org/10.1016/j.tourman.2009.07.011

Chen, M.H. (2011). The response of hotel performance to international tourism development and crisis events. International Journal of Hospitality Management, 30(1), 200-212, doi 10.1016/j.ijhm.2010.06.005

Cherniavska, O. (2015). Theoretical approaches to the determination of the phenomenon of «technoglobalism», Torun International Studies, 1(8), 5-12.

Cheung, C., Kong, H., \& Song, H. (2014). How to influence hospitality employee perceptions on hotel brand performance? International Journal of Contemporary Hospitality Management, 26(8), 1162-1178, doi 10.1108/IJCHM02-2013-0090

Claver-Cortes, E., Molina-Azorin, J.F., \& Pereira-Moliner, J. (2006). Strategic groups in the hospitality industry: Intergroup and intragroup performance differences in Alicante, Spain. Tourism Management, 27(6), 1101-1116, doi 10.1016/j.tourman.2005.11.006

Costa V., \& Costa C. (2019). Competitiveness and Business Performance in the Portuguese Hotel Industry. Proceedings of the 2nd International Conference on Tourism Research (ICTR 2019), 28-36.

Dimitric, M., Zikovic, I.T., \& Blecich, A.A. (2019). Profitability determinants of hotel companies in selected Mediterranean countries. Economic Research - Ekonomska Istrazivanja, 32(1), 1977-1993, doi 10.1080/1331677X.2019.1642785

Fayissa B., Nsiah C., \& Tadasse B. (2008). Impact of Tourism on Economic Growth and Development in Africa. Tourism Economics, 14(4), 807-818. doi 10.5367/000000008786440229 
Hanafiah M.H., Hemdi M.A., \& Ahmad I. (2016). Does tourism destination competitiveness lead to performance? A case of ASEAN region. Tourism, 64(3), 251-260

Hiadlovsky V., Rybovicova I., \& Vinczeova M. (2016). Importance of liquidity analysis in the process of financial management of companies operating in the tourism sector in slovakia: an empirical study. International Journal for Quality Research, 10(4), 799-811. doi 10.18421/IJQR10.04-10

International Labour Office. (1989). Productivity and training in the hotel, catering and tourism sector. Hotel, Catering and Tourism Committee, Geneva, Switzerland: International Labour Office.

Israeli A.A. (2002). Star rating and corporate affiliation: Their influence on room price and performance of hotels in Israel. International Journal of Hospitality Management, 21(4), 405-424.

Jankowska, E. (2014). Social indicators and the measure of the quality of life, Torun International Studies, 1(7), 5-13.

Jagels M.G., (2007). Hospitality management accounting. 9th ed. John Wiley and Sons

Joppe M., \&Li X.P. (2016). Productivity measurement in tourism the need for better tools. Journal of Travel Research, 55(2), 139-149, doi:10.1177/0047287514546227

Kliestik, T., Valaskova, K., Lazaroiu, G., Kovacova, M., \& Vrbka, J. (2020). Remaining Financially Healthy and Competitive: The Role of Financial Predictors. Journal of Competitiveness, 12(1), 74-92,doi 10.7441/joc.2020.01.05

Ključnikov, A., Krajčík, V., \& Vincúrová, Z. (2018). International Sharing Economy: the Case of AirBnB in the Czech Republic. Economics and Sociology, 11(2), 126-137. doi:10.14254/2071-789X.2018/11-2/9

Krawiec, M., \& Noga, M. (2017). Conceptualizing creative economy. Torun International Studies, 1(10), 127-137.

Lipianin-Zontek, E, \& Szewczyk, I. (2019). Adaptation of business hotels to the needs of disabled tourists in Poland. Problems and Perspectives in Management, 17(4), 392-403. doi:10.21511/ppm.17(4).2019.32

Liu A., \& Wu D.C. (2019). Tourism productivity and economic growth. Annals of Tourism Research, 76, 253-265, doi:10.1016/j.annals.2019.04.005

Lukianenko, D., Poruchnik, A., Stoliarchuk, Y., \& Liutak, O. (2019). Globalization of the tourism industry: scales, levels and institutional formats. Problems and Perspectives in Management, 17(2), 563-574. doi:10.21511/ppm.17(2).2019.44

Matijová, M., Onuferová, E., Rigelský, E., Stanko, V. (2019). Impact of Selected Indicators of Tourism Capacity and Performance in the Context of the Unemployment Rate in Slovakia. Journal of Tourism and Services, 10(19): 1-23, doi:10.29036/jots.v10i19.95

Mattsson, J.,\& Orfila-Sintes, F. (2014). Hotel innovation and its effect on business performance. International Journal of Tourism Research, 16(4), 388-398, doi 10.1002/jtr.1933

McNamara, G., Deephouse, D.L., \& Luce, R.A. (2003). Competitive Positioning within and across a Strategic Group Structure: The Performance of Core, Secondary and Solitary Firms. Strategic Management Journal, 24(2), 161-181, doi:10.1002/smj.289

Mucharreira, P.R., Antunes, M.G., Abranja, N., Justino, M. R. T., \& Quiros, J.T. (2019). The relevance of tourism in financial sustainability of hotels. European Research on Management and Business Economics, 25(3), 165-174, doi:10.1016/j.iedeen.2019.07.002

Oliveira, R., Pedro, M.I., \& Marques, R.C. (2013). Efficiency performance of the Algarve hotels using a revenue function. International Journal of Hospitality Management, 35, 59-67, doi 10.1016/j.ijhm.2013.05.005

Pablo-Romero M.P.,\& Molina J.A. (2013). Tourism and economic growth: A review of empirical literature. Tourism Management Perspectives, 8, 28-41, doi 10.1016/j.tmp.2013.05.006

Pacheco, L. (2019). Performance vs. Family Ownership and Management: The Case of Portuguese Wine Firms. Entrepreneurial Business and Economics Review, 7(3), 7-24. https://doi.org/10.15678/EBER.2019.070301

Pereira-Moliner J., Claver-Cortes E.,\& Molina-Azorin J.F. (2011). Explaining the Strategic Groups-Firm Performance Relationship: A Multilevel Approach Applied to Small and Medium-Sized Hotel Companies in Spain. Journal of Small Business Management, 49(3), 411-437, doi 10.1111/j.1540-627X.2011.00330.x

Phillips P., Barnes S., Zigan K., \&Schegg R. (2017). Understanding the Impact of Online Reviews on Hotel Performance: An Empirical Analysis. Journal of Travel Research, 56(2), 235-249, doi: 10.1177/0047287516636481

Pinteric, U. (2017). Understanding political and economic transition in Post-Yugoslav Serbia and Slovenia, Torun International Studies, 1(10), 155-165. 
Pine, R., \& Phillips, P.A. (2005). Performance comparison of hotels in China. International Journal of Hospitality Management, 24(1), 57-73, doi 10.1016/j.ijhm.2004.04.004

Redo, M. (2015). An analysis of economic changes in the countries of Central and Eastern Europe belonging to the European Union in the years 2003-2014, Torun International Studies, 1(8), 83-97

Richard, P.J., Devinney, T.M., Yip, G.S., \& Johnson, G. (2009). Measuring Organizational Performance: Towards Methodological Best Practice. Journal of Management, 35(3), 718-804, doi:10.1177/0149206308330560

Roskladka, A., Roskladka, N., Dluhopolskyi, O., Kharlamova, G., \& Kiziloglu, M. (2018). Data analysis and forecasting of tourism development in Ukraine. Innovative Marketing , 14, 19-33. doi:10.21511/im.14(4).2018.02

Sainaghi, R., Phillips, P., \& Corti V. (2013). Measuring hotel performance: Using a balanced scorecard perspectives' approach. International Journal of Contemporary Hospitality Management, 34(1), 150-159, doi:10.1016/j.ijhm.2013.02.008

Sainaghi, R., Phillips, P., \& Zavarrone, E. (2017). Performance measurement in tourism firms: A content analytical meta-approach. Tourism Management, 59, 36-56, doi 10.1016/j.tourman.2016.07.002

Saleh, M. M. A., Jawabreh, O.A.A., Alsarayreh, M.N., \& Malkawi, E. (2018). Environmental accounting as perspective for hotels of Aqaba special economic zone authority (ASEZA) . Problems and Perspectives in Management, 16(4), 169-185. doi:10.21511/ppm.16(4).2018.15

Siskos, E., \& Darvidou, K. (2018). Bilateral trade and tourism relations between the EU and BSEC countries. Problems and Perspectives in Management, 16(4), 91-101. doi:10.21511/ppm.16(4).2018.09

Skuflic, L., \& Mlinaric, D. (2015). Microeconomic Determinants Of Profitability For Croatian Hotel Industry. Ekonomski Pregled, 66(5), 477-494.

Stefko, R., Vasanicova, P., Litavcova, E., \& Jencova, S. (2018). Tourism Intensity in the NUTS III Regions of Slovakia. Journal of Tourism and Services, 9(16), doi: 10.29036/jots.v9i16.43

VG. (2020). About the Visegrad Group. Available online: http://www.visegradgroup.eu/about (accessed on 7 May 2020).

Vila, M., Costa, G., \& Rovira, X. (2010). The creation and use of scorecards in tourism planning: A Spanish example. Tourism Management, 31, 232-239, doi 10.1016/j.tourman.2009.02.015

Vozarova, I.K., Kotulic, R., \& Vavrek, R. (2019). Disparities in the financial performance of agricultural entities according to the legal form: the case of Slovakia, Applied Economics, 51(56), 5999-6008, doi:10.1080/00036846.2019.1645285

Xiao Q., O'Neill J.W.,\& Mattila A. S. (2012). The role of hotel owners: the influence of corporate strategies on hotel performance. International Journal of Contemporary Hospitality Management, 24(1), 122-139, doi:10.1108/09596111211197836

Yang, Z., \& Cai J. (2016). Do regional factors matter? Determinants of hotel industry performance in China. Tourism Management, 52, 242-253, doi 10.1016/j.tourman.2015.06.024

Yang, Z., Xia, L., \& Cheng, Z. (2017). Performance of Chinese hotel segment markets: Efficiencies measure based on both endogenous and exogenous factors. Journal of Hospitality and Tourism Management, 32, 12-23, doi:10.1016/j.jhtm.2017.04.007 